\title{
LY2109761, Transforming Growth Factor $\beta$ Receptor Type I and Type II Dual Inhibitor, is a Novel Approach to Suppress Endothelial Mesenchymal Transformation in Human Corneal Endothelial Cells
}

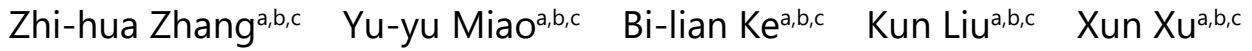 \\ aShanghai Key Laboratory of Ocular Fundus Diseases, Shanghai, 'Department of Ophthalmology, \\ Shanghai General Hospital, Shanghai Jiao Tong University, Shanghai, 'Shanghai Engineering Center for \\ Visual Science and Photomedicine, Shanghai, China
}

\section{Key Words}

Corneal endothelial cells • Endothelial-mesenchymal transformation • LY2109761 • TGF- $\beta$

\begin{abstract}
Background/Aims: Preventing undesirable endothelial-mesenchymal transformation (EnMT) with repetitious in vitro expansion of human corneal endothelial cells (CECs) is a pivotal issue in cornea regeneration. Previous studies have shown that inhibition of the TGF- $\beta$ pathway reduces epithelial-mesenchymal transformation. However, its potential role in EnMT remains poorly understood. As such, the effect of LY2109761, a novel TGF- $\beta$ receptor type I and type II dual inhibitor, was investigated on EnMT. Methods: CECs cultured with various concentrations of LY2109761 were evaluated for their growth rate and phenotype. Additionally, the expression of functional markers (sodium-potassium pump Na+$/ \mathrm{K}^{+}$-ATPase and the tight junction protein ZO-1) and mesenchymal markers (CD73, fibronectin, and vimentin) was detected using immunostaining and western blot. The mRNA expressions were also assayed by real-time polymerase chain reaction analysis. Results: At a $1 \mu \mathrm{M}$ concentration, LY2109761 did not influence the proliferation of CECs and subsequent experiments were therefore performed using this concentration. Furthermore, CECs cultured in the presence of $1 \mu \mathrm{M}$ LY2109761 maintained their ability to grow as a monolayer of hexagonal-shaped cells. The expression of functional markers increased in LY2109761-treated CECs, while the expression of mesenchymal markers decreased (both in protein and mRNA levels). Conclusion: Inhibition of TGF- $\beta$ receptor type I and type II by LY2109761 maintained the phenotype of CECS and inhibited the EnMT process. These results indicate the possible continuous in vitro expansion of CECs with normal function.

Z.-h. Zhang and Y.-y. Miao contributed equally to this work.

Dr. Kun Liu

and Dr. Bi-lian Ke

Department of Ophthalmology, Shanghai General Hospital, Shanghai Jiao Tong University

100 Haining Road, Shanghai, 200080 (China)

Tel.86-21-36123480, Fax 86-21-36123480,E-Mail drliukun@sjtu.edu.cn; kebilian@126.com
\end{abstract}




\section{Cellular Physiology Cell Physiol Biochem 2018;50:963-972 \begin{tabular}{ll|l} 
and $10.1159 / 000494480$ & $\begin{array}{l}\text { O } 2018 \text { The Author(s). Published by S. Karger AG, Basel } \\
\text { www.karger.com/cpb }\end{array}$
\end{tabular} \\ Zhang et al.: LY2109761 Inhibits Endothelial Mesenchymal Transformation}

\section{Introduction}

The corneal endothelium layer maintains corneal transparency by balancing its hydration through barrier and pump functions $[1,2]$. Damage of the hexagonal-shaped corneal endothelial cells (CECs) can cause severe visual impairment and can even lead to blindness [3]. As no pharmaceutical intervention has yet been introduced into clinical settings, the only treatment available is corneal transplantation, which includes penetrating keratoplasty and endothelial keratoplasty. However, both transplantations require grafts containing functional CECs of high density, which is highly restricted by the shortage of donor corneas. Hence, successful engineering of surgical grafts with functional CECs will have a significant impact on the treatment of corneal blindness.

In 2015, we demonstrated that CECs isolated from discarded human corneal tissues could form a monolayer on a scaffold and manifest normal physiological function [4]. We also found that CECs were vulnerable to morphological fibroblastic change in vitro and eventually underwent massive endothelial-mesenchymal transformation (EnMT) and lost function-related marker expression after long-term culture or multiple subculture during expansion. Thus, the crucial goal is to prevent these undesirable cellular changes, so that the continuous in vitro expansion of CECs from discarded tissues can be achieved.

Recently, studies have suggested that the TGF- $\beta$ signaling pathway might be an important pathway involved with the fibroblastic change of CECs [5, 6]. Furthermore, additional studies have also shown that CECs were prone to acquire fibroblastic phenotypes in response to TGF- $\beta$ stimulation, and that blocking the TGF- $\beta$ signaling pathway maintained the cell morphology [6-9]. LY2109761 is. Previous studies have showed that LY2109761, a novel TGF- $\beta$ receptor type I (T $\beta R I)$ and type II (T $\beta$ RII) dual inhibitor, could effectively reverse the epithelial-tomesenchymal transition (EMT) in vitro as well as in vivo $[10,11]$. In the present study, we investigated the potential role of LY2109761 on EnMT in vitro by evaluating LY2109761treated CECs for their proliferation, morphology, and function-associated marker expression.

\section{Materials and Methods}

\section{Ethical statement}

Discarded cornea tissues were obtained from the Ddepartment of Oophthalmology, Shanghai General Hospital. This study was performed in accordance with the tenets of the Declaration of Helsinki and approved by the ethics committee of Shanghai General Hospital. For all donors, written consent was obtained from the next of kin regarding eye donation for research.

\section{Cell culture}

A total of six human donor corneoscelral rims were used for the cultivation of CECs based on the protocol described previously [4]. Briefly, the limbal Descemet's membrane was scraped and immersed in $0.2 \%$ collagenase II (278 U mg-1, Worthington Biochemical Co., Lakewood, NJ, USA), which was dissolved in endothelial growth medium-2 (EGM-2; Lonza, Walkersville, MD, USA; Catalog No CC-4176), for 1h at $37^{\circ} \mathrm{C}$. The cells were then released by gently pipetting the dissolved membrane with a Pasteur pipette, followed by resuspending the cell pellets in TryPLE Express (Invitrogen, Camarillo, CA, USA) for 5 min at $37^{\circ} \mathrm{C}$. After that, the cells were resuspended and seeded in 6-well tissue-culture plates pre-coated with FNC Coating Mix (Athena Environmental Sciences, Baltimore, MD, USA). The culture media was supplemented with $0.1 \%$ epidermal growth factor (EGF), $0.1 \%$ vascular endothelial growth factor (VEGF), $0.4 \%$ fibroblast growth factor (FGF), $0.1 \%$ insulin-like growth factor (IGF), $0.04 \%$ hydrocortisone, $0.1 \%$ ascorbic acid, $0.1 \%$ heparin, $5 \mu \mathrm{g} / \mathrm{ml}$ gentamicin, $0.25 \mu \mathrm{g} / \mathrm{ml}$ amphotericin-B and $2 \%$ FBS. The culture medium was changed every 3 days. Cells were sub-cultured by treating with TryPLE Express upon reaching confluency. Passages 2 to 5 were used for all experiments. 


\section{Cellular Physiology Cell Physiol Biochem 2018;50:963-972 \begin{tabular}{l|l|l} 
and Biochemistry Published onlIne: 23 October 2018 & $\begin{array}{l}\text { (c) } 2018 \text { The Author(s). Published by S. Karger AG, Basel } \\
\text { www.karger.com/cpb }\end{array}$ \\
\hline
\end{tabular} \\ Zhang et al.: LY2109761 Inhibits Endothelial Mesenchymal Transformation}

\section{Treatment of TGF- $\beta$ receptor inhibitor in CECS}

LY2109761 (Selleck, Houston, TX, USA) was dissolved in dimethyl sulfoxide (DMSO) and diluted to 0.1, 1 and $10 \mu$ M with EGM-2 [DMSO final concentration, $0.1 \%(\mathrm{v} / \mathrm{v})$ ]. The CECs were passaged at a ratio of 1:2 with culture medium supplemented with or without LY2109761 $(0.1,1$, and 10 $\mu \mathrm{m})$. LY2109761 was only added to the medium when the cells were passaged. After 3 to 5 days, cell proliferation and gene and protein expression were evaluated as described below.

\section{Cell proliferation}

CECs were seeded at a density of 130 cells/mm2 and cultured for up to 4 days with or without LY2109761 $(0.1,1$, and $10 \mu \mathrm{M})$. Cell proliferation was determined at day 1, 2 and 4 post-seeding with the use of CyQUANT ${ }^{\circledR N F}$ Cell Proliferation Assay Kit (Invitrogen, Camarillo, CA, USA). Cell proliferation was measured by the intensity of fluorescence detected from each sample with a fluorescence microplate reader at an excitation of $485 \mathrm{~nm}$ and an emission detection of $530 \mathrm{~nm}$. All the samples were tested in triplicate, and the results expressed as a proliferation curve.

\section{Characterization and inmmunostaining of CECs}

Cell morphology was evaluated by using an inverted light microscope (Olympus IX-71, Tokoyo, Japan). The CECs were further characterized for function-related markers, including Na+/K+-ATPase (a pump function associated protein [12]), and zona occludens-1 (ZO-1, a tight junction associated protein [13]). Changes of the EnMT were also evaluated by investigating CD73 (a marker to determine the fibroblastic phenotype of CEC [14]), and fibronectin $[15,16]$ and vimentin $[17,18]$ (two mesenchymal markers). Briefly, the cultured cells were first fixed with cold methanol for 20 min. After blocking with Protein Block SerumFree solution (DAKO, Carpinteria, CA, USA), the cultured cells were incubated overnight with the following primary antibodies: anti-Na+/K+-ATPase (1:300 dilution, Millipore), anti-ZO-1 (1:150 dilution, Invitrogen), anti-CD73 (1:300 dilution; BD Pharmingen Stain Buffer), anti-fibronectin (1:200 dilution, Sigma-Aldrich), and anti-vimentin (1:100 dilution; Santa Cruz). Fluorescein isothiocyanate (FITC) conjugated antibodies (1:200 dilution, Vector Laboratories, Burlingame, CA) were used as the secondary antibodies.

\section{Western blot analysis}

Cells treated with and without LY2109761 (0.1 and $1 \mu \mathrm{M})$ were washed with phosphate buffered saline (PBS) and lysed in Radio-Immunoprecipitation Assay (RIPA) buffer (Thermo Fisher, Rockford, IL, USA) containing 1\% phenylmethyl-sulfonyl fluoride (PMSF). The protein concentrations of the samples were then assessed with the BCATM Protein Assay Kit (Takara Bio Inc., Otsu, Japan). Cell lysates (containing each an amount of $30 \mu \mathrm{g}$ protein) were separated by $10 \%$ SDS-PAGE gels electrophoresis and transferred to a PVDF membrane (Bio-Rad, Hercules, CA, USA). The membrane was then blocked in Tris-buffered saline/Tween20 (TBST) buffer containing 5\% non-fat milk powder for $2 \mathrm{~h}$ at room temperature. The membranes were then probed overnight at $4{ }^{\circ} \mathrm{C}$ with the following primary antibodies: anti-Na+/K+-ATPase, anti-ZO-1, anti-CD73, anti-fibronectin, and anti-vimentin. Furthermore, the primary antibodies anti-phosphorylated Smad2 (Cell Signaling Technology), anti-phosphorylated Erk1/2 (BD), and anti-phosphorylated p38 (BD) were used to determine the inhibition effect of LY2109761 on the TGF- $\beta$ signaling pathway $(0.1$ and $1 \mu$ M LY2109761treated samples). For all samples, anti-GAPDH was used as a housekeeping gene. After incubated with horseradish peroxidase (HRP)-conjugated secondary antibodies for $1 \mathrm{~h}$ at room temperature, protein signal was detected with the ECL chemiluminescent detection system (Bio-Rad). All sample protein values were normalized with the GAPDH expression.

Real-time polymerase chain reaction (PCR) analysis

Total RNA was extracted from CECs using Trizol (Invitrogen). The cDNA was synthesized with the PrimeScript $®$ RT reagent Kit (Perfect Real Time) (Takara Bio Inc., Toyobo, Osaka, Japan). Gene transcription levels were quantified using the SYBR $®$ Premix Ex Taq ${ }^{\mathrm{TM}}$ (Perfect Real Time) (Takara Bio Inc., Toyobo, Osaka, Japan) according to the manufacturer's recommended cycling conditions. The specific primers used were listed as follows:

GAPDH, forward: 5'- GGAGCGAGATCCCTCCAAAAT-3'

reverse: 5'- GGCTGTTGTCATACTTCTCATGG-3'

$\mathrm{Na}+$ /K+-ATPase, forward: 5'-CTTCCTCCGCATTTATGCTCATTTTCTCACCC-3' 


\title{
Cellular Physiology Cell Physiol Biochem 2018;50:963-972

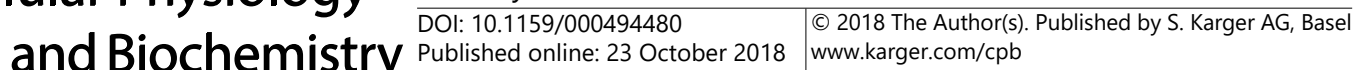

\author{
reverse: 5'-GGATGATCATAAACTTAGCCTTGATGAACTC-3' \\ ZO-1, forward: 5'-GGACGAGGCATCATCCCTAA-3' \\ reverse: 5'-CCAGCTTCTCGAAGAACCAC-3' \\ CD73, forward: 5' - CTCCTCTCAATCATGCCGCT-3' \\ reverse: 5' - CATCAATGGGCGACCGGATA-3' \\ Fibronectin, forward: 5'- GAGGCACCACGAGAAGTGAC -3' \\ reverse: 5' - GCACTCCAGTGTCAGGGTTT-3' \\ Vimentin, forward: 5'-GGACCAGCTAACCAACGACA-3' \\ reverse: 5'-AAGGTCAAGACGTGCCAGAG-3'
}

GAPDH was used as an endogenous control. All the samples were detected in triplicate for each experiment. All results shown are representatives of three independent experiments. Expression levels of mRNA were calculated with the delta-delta Ct method $\left(2^{-\Delta \Delta C t}\right)$.

\section{Statistical analysis}

Data analyses were performed by the SPSS software (Version 13.0, Chicago, IL, USA). Statistical significance between two groups was determined by using the Student's t-test. The statistical significance in the comparison of multiple groups was carried out using the one-way analysis of variance. Additionally, comparisons between each two groups were made by least significant difference (LSD) analysis. All values were expressed as the mean \pm standard deviation (SD). P values $\leq 0.05$ were considered statistically significant.

\section{Results}

Cell growth ofCEC cultures and inhibition of the TGF- $\beta$ signaling pathway with and without LY2109761

The growth rates of CECs cultured with LY2109761 $(0.1,1$, and $10 \mu \mathrm{M})$ and without (control group) were evaluated and compared to each other (Fig. 1). Two days after seeding, there were significantly more CECs for the 1- $\mu$ M LY2109761 group compared to the control group $(\mathrm{P}=0.044)$ but no difference thereafter. For the 10- $\mu \mathrm{M}$ LY2109761 group, significantly less CECs were found 4 days after seeding compared to the control group ( $\mathrm{P}=0.019)$. Next, western blot analysis showed that phosphorylation of Smad2, Erk1/2, and p38 decreased in cells cultured with LY2109761 in a concentration-dependent manner compared to cells cultured without (Fig. 2). Overall, LY2109761 did not influence CECs the proliferation of CECs at a $1-\mu \mathrm{M}$ concentration but did inhibit the TGF- $\beta$ signaling pathway. Therefore, for additional experiments, CECs were cultured with $1 \mu \mathrm{M}$ of LY2109761 to evaluate its effect on the EnMT process.

Fig. 1. The effect of TGF- $\beta$ signaling inhibition on CECs proliferation. The CECs were cultured with the TGF- $\beta$ inhibitor LY2109726 in concentration groups of $0.1,1$, and $10 \mu \mathrm{M}$ or without as a control (DMSO only). The cell number of each treatment was measured by a fluorescence-based cell proliferation assay on days 1, 2, and 4. Each concentration group was tested in three independent experiments. The mean value of the fluorescence signal of each group is shown with SD as error bar $(*, P<0.05$ compared with control group).

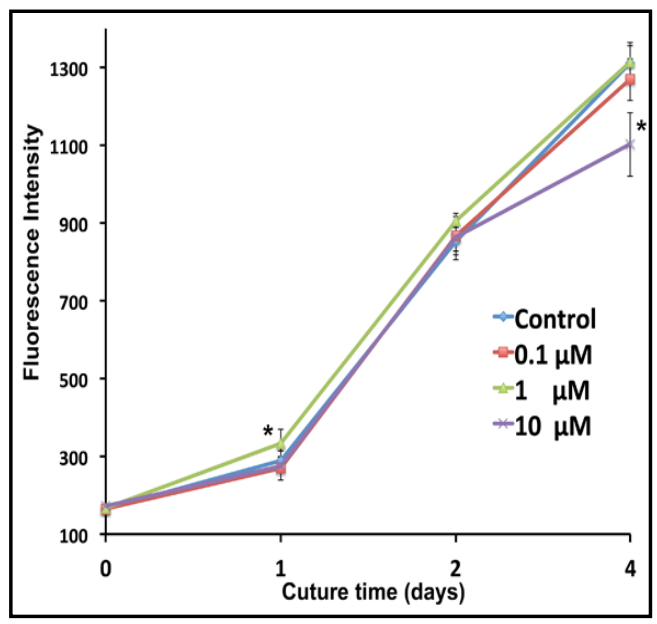




\section{Cellular Physiology \begin{tabular}{ll|l} 
and Biochemistry Published OnIIne: 23 October 2018 & $\begin{array}{l}\text { (c) } 2018 \text { The Author(s). Published by S. Karger AG, Basel } \\
\text { www.karger.com/cpb }\end{array}$ \\
\hline
\end{tabular} \\ Zhang et al.: LY2109761 Inhibits Endothelial Mesenchymal Transformation}

LY2109761 at a 1 $\mu M \quad$ concentration inhibits EnMT in human CECS

Firstly, the phenotypes of CEC cultures treated with and without LY2109761 $(1 \mu \mathrm{M})$ in the culture medium were examined. R e p r e s e n t a t i v e microscopic images of CECs cultured with and without LY2109761 at passages 3 and 5 are shown in Fig. 3. During the whole culture period, CECs cultured in the presence of LY2109761 maintained their ability to grow as a monolayer of hexagonal-shaped cells, while the control CECs gradually exhibited the fibroblastic morphology after subsequent subcultures. Secondly, to confirm EnMT inhibition effect of LY2109761 in human CECs, the expression of functional proteins and fibroblastic proteins were evaluated by immunostaining. The results showed an increased expression for both the sodiumpotassium pump $\mathrm{Na}^{+} /$ $\mathrm{K}^{+}$-ATPase and the tight junction protein $\mathrm{ZO}-1$ in the LY2109761-treated $(1 \mu \mathrm{M})$ CECs (Fig. 4). In contrast, the expression of mesenchymal proteins CD73, fibronectin and vimentin decreased in the LY2109761-treated CECs (Fig. 5). Together, these data indicated that inhibition of T $\beta$ RI and T $\beta$ RII by LY2109761 maintained the polygonal monolayer properties of CECs and decreased the EnMT process.

Moreover, western blot analysis of CEC cultures treated with and without $1 \mu \mathrm{M}$ of LY2109761 was performed (Fig. 6). Consistent with the immunostaining data, the results showed a 2.03-fold upregulation of the $\mathrm{Na}^{+} / \mathrm{K}^{+}$-ATPase protein level and a 1.78fold upregulation of the ZO-1 protein level in the LY2109761-treated CECs compared to the control. These results confirmed that LY2109761-treated CECs were associated with a significantly higher expression of function-related proteins. Also, $1 \mu \mathrm{M} \mathrm{LY2109761}$ significantly downregulated the expression of fibronectin, CD73, and vimentin by 1.70-fold, 2.69-fold, and 2.71-fold, respectively.
Fig. 2. The inhibition effect of LY2109761 on the TGF- $\beta$ signaling pathway. The CECs were cultured with LY2109726 (0.1 and $1 \mu \mathrm{M})$ and without (control). Phosphorylation of Smad2, p38, and Erk1/2 was decreased by LY2109761 in a concentration-dependent manner. GAPDH was used as an endogenous control.

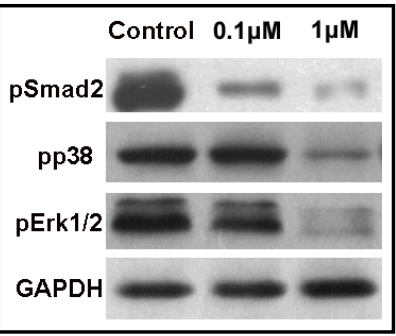

Fig. 3. In vitro culture of CECs at different p a s s a g e s. Representative light microscopy images were taken of CECs cultured with $1 \mu \mathrm{M} \quad \mathrm{LY} 2109761$ and without (control) at culture passages 3 and 5 (scale bar $=100 \mu \mathrm{m})$.

Fig.

Characterization of functionrelated markers by immunostaining. CECs cultured with $1 \mu \mathrm{M} \quad \mathrm{LY} 2109761$ and without (control) were i m m un os tain ed with antibodies against $\mathrm{Na}+\mathrm{K}+-$ ATPase and ZO-1

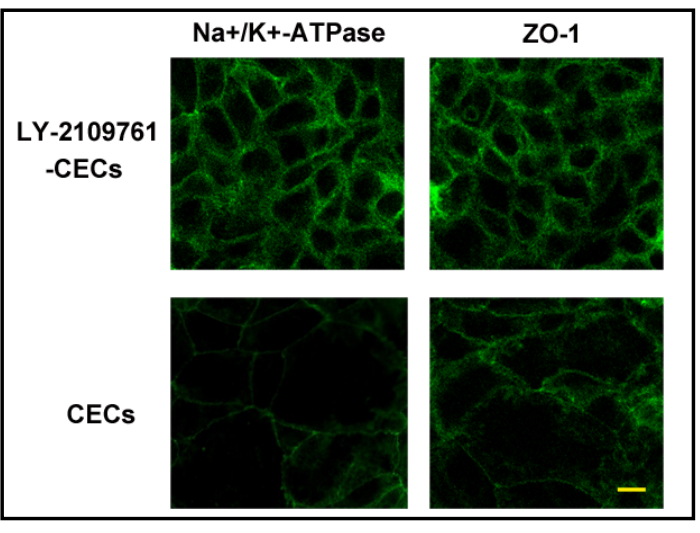
Cells at passage 4 were used for all the stainings. Immunostaining was performed 2 days after the cells had reached confluency (scale bar $=25 \mu \mathrm{m}$ ). 


\section{Cellular Physiology Cell Physiol Biochem 2018;50:963-972 \begin{tabular}{ll|l} 
DOI: 10.1159/000494480 & O 2018 The Author(s). Published by S. Karger AG, Basel \\
and Biochemistry
\end{tabular}

Fig. 5. Investigating of changes of the EnMT by immunostaining. CECs cultured with $1 \mu \mathrm{M}$ LY2109761 and without (control) were immunostained with antibodies against CD73 (in green), fibronectin (in red), and vimentin (in red). Cell nuclei were counterstained with 4',6-diamidino-2-phenylindole (DAPI, blue). Cells at passage 5 were used for the fibronectin staining, and the result showed that cells cultured

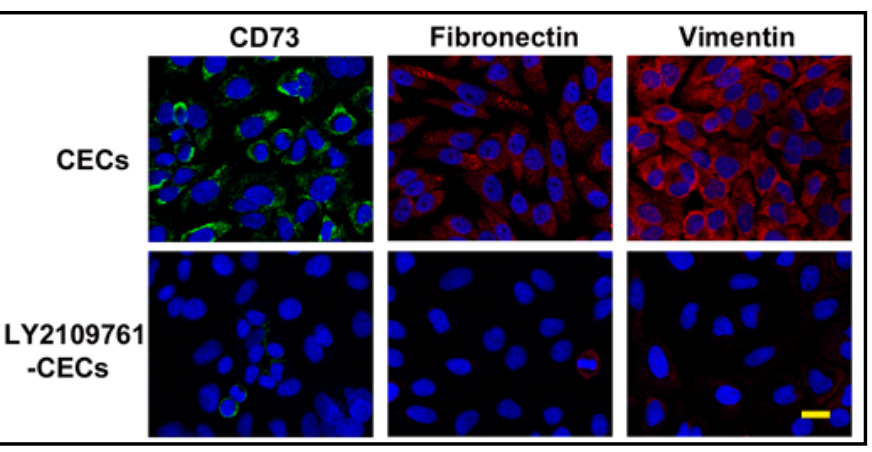
without LY2109761 had fibroblastic cell shape. Cells at passage 3 were used for all the other stainings. Immunostaining was performed 3 days after seeding (scale bar $=25 \mu \mathrm{m})$.

Fig. 6. Western blot analysis of CECs treated with $1 \mu \mathrm{M}$ of LY2109726 and without (control). The expression of functional-markers $\mathrm{Na}+/ \mathrm{K}+-\mathrm{ATPase}$ and $\mathrm{ZO}-1$, as well as mesenchymal markers CD73, fibronectin and vimentin, was assessed at protein level. The relative expression of proteins was calculated by using GAPDH as an endogenous control for normalization, followed by normalizing the protein levels in the control group to 1.0. Each group

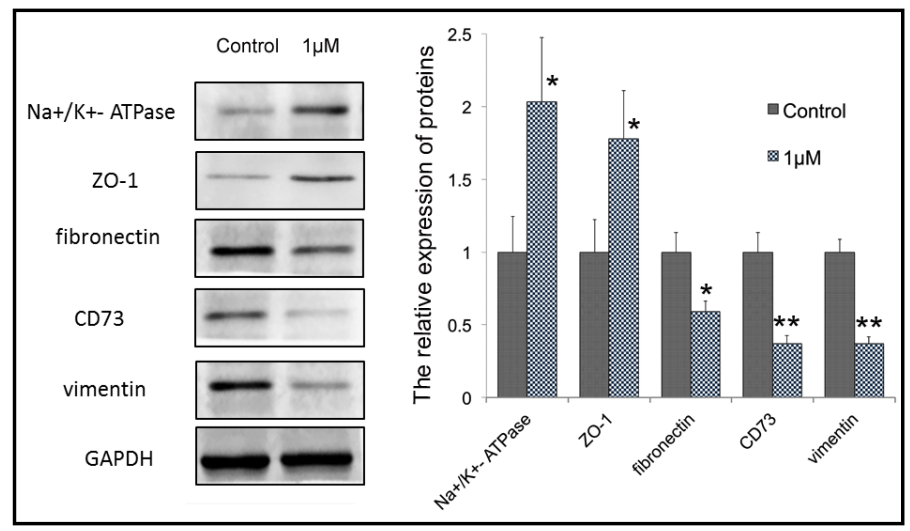
was tested in three independent

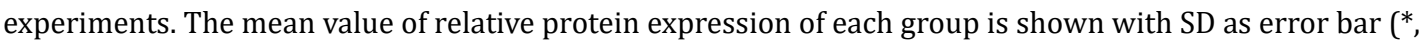
$\mathrm{P}<0.05$; ${ }^{* *}, \mathrm{P}<0.01$ ). For all experiments, CECs at passage 4 were used 2 days after having reached confluency.

Fig. 7. Real time PCR analysis of CECs. CECs were cultured with $1 \mu \mathrm{M}$ LY2109726 or without (control). The expression of functional-markers $\mathrm{Na}+\mathrm{K}+-\mathrm{ATPase}$ and ZO-1, as well as mesenchymal markers CD73, fibronectin and vimentin, was assessed at RNA level for both treatment groups. The relative expression of proteins was calculated by using GAPDH as an endogenous control for normalization, followed by normalizing the protein levels in the control group to 1.0. Each group was tested in three independent experiments. The mean value of relative RNA expression of each group is shown with $\mathrm{SD}$ as error bar $\left({ }^{*}, \mathrm{P}<0.05\right.$; **, $\left.\mathrm{P}<0.01\right)$. For all experiments, CECs at passage 3 were used 2 days after having reached confluency.

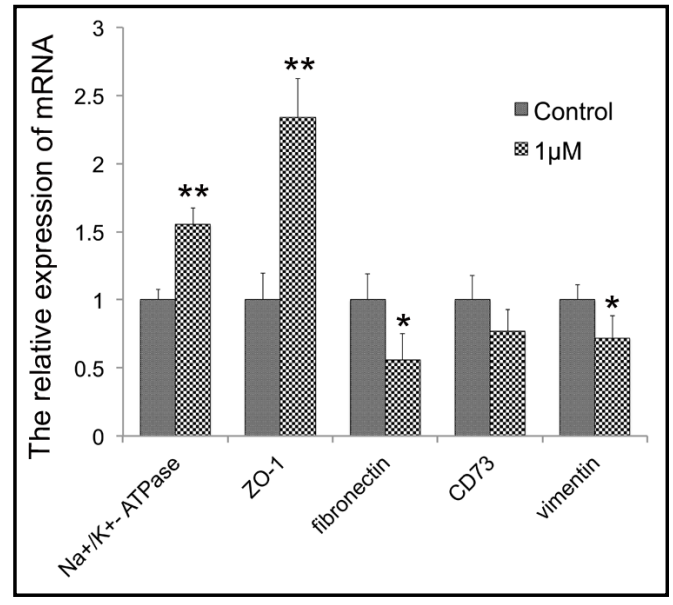

To further confirm the expression change of the indicated markers, real-time PCR analysis was employed to evaluate the mRNA levels. For functional proteins, a 1.55-fold increase for $\mathrm{Na}^{+} / \mathrm{K}^{+}$-ATPase and a 2.34-fold increase for Z0-1 were found. For mesenchymal proteins, a 1.78-fold decrease for fibronectin, a 1.31-fold decrease for CD73, and a 1.39fold decrease for vimentin were found (Fig. 7). Taken together, these data supported that LY2109761 at $1 \mu \mathrm{M}$ could effectively block the EnMT. 


\section{Cellular Physiology Cell Physiol Biochem 2018;50:963-972 \begin{tabular}{ll|l|l} 
and Biochemistry & $\begin{array}{l}\text { DOl: 10.1159/000494480 } \\
\text { Published online: } 23 \text { October } 2018\end{array}$ & $\begin{array}{l}\text { O } 2018 \text { The Author(s). Published by S. Karger AG, Basel } \\
\text { www.karger.com/cpb }\end{array}$ \\
\cline { 2 - 3 }
\end{tabular} \\ Zhang et al.: LY2109761 Inhibits Endothelial Mesenchymal Transformation}

\section{Discussion}

In the past decade, corneal transplantation has improved greatly. Advances in lamellar keratoplasty have made it possible to transplant only posterior corneas for corneal endothelial diseases, collectively termed "endothelial keratoplasty" [19, 20]. Along with technique improvements, more conditions have become treatable, and the demand for corneal tissue has therefore increased [21]. However, the number of donated corneas for transplantation has not increased along with demands [22,23]. For this reason, there has become a need for tissue-engineered substitutes that can overcome this scarcity. For this reason, the establishment of an efficient cultivation technique for functional CECs is an essential and inevitable part for the tissue engineering of endothelium [24].

The role of TGF- $\beta$ as a key molecule in the development and progression of EMT has been well characterized and studied $[25,26]$. Recently, several studies have suggested that TGF- $\beta$ signaling might also exert a similarly important role regarding the fibroblastic change of CECs [5-9]. TGF- $\beta$ initiates mesenchymal transformation by binding to T $\beta$ RI and T $\beta$ RII, which allows for the constitutively active T $\beta$ RII kinase to transphosphorylate and activate the T $\beta R I$ kinase. This activation leads to the propagation of the signal by activating downstream Smad-dependent and Smad-independent pathways [27-30]. Okumura et al. [6] reported that the specific inhibitor to the T $\beta R I$ was able to maintain CECs in a polygonal phenotype with a higher expression of function-related markers. However, T $\beta$ RII possesses a tyrosine kinase activity and enables the phosphorylation of the Smad-independent signaling pathway [31]. So, if only T $\beta R I$ was inhibited, a higher expression ratio of T $\beta R I I$ compared to T $\beta R I$ would still activate the EnMT via the non-canonical Smad signaling pathway [32]. Therefore, in this study, we employed LY2109761, a dual inhibitor of T $\beta R I$ and T $\beta$ RII, to prevent CECs from acquiring fibroblastic phenotypes.

TGF- $\beta$ regulates a wide range of cellular behavior. Studies have shown that blocking TGF- $\beta$ resulted in various effects on cell proliferation [33-36]. To test LY2109761's effect on CECs proliferation, we evaluated the growth rates of CECs cultured with and without LY2109761. For CECs cultured with $1 \mu \mathrm{M}$ of LY2109761, there were significantly more CECs found compared to the control group on day 2 of post-seeding. Additional days after seeding, however, did not show a significant difference. For CECs cultured with $10 \mu \mathrm{M}$ of LY2109761, there were significantly less HCECs found compared to the control group on day 4 of postseeding. These results indicate that LY2109761, at a concentration of $10 \mu \mathrm{M}$, might influence the normal growth of CECs.

Next, we also found that the phosphorylation of Smad2, p38, and Erk1/2 was decreased by LY2109761 in a concentration-dependent manner. After evaluating the results, we continued with $1 \mu \mathrm{M}$ of LY2109761 as the focus point of this study; however, future studies should further determine the most optimal concentration to inhibit EnMT effectively without interfering with the cell growth.

To the best of our knowledge, this currently presented study is the first to focus on the potential effect of the dual inhibitor LY2109761 on EnMT in vitro. Our results demonstrated that LY2109761 completely abolished the undesirable cellular changes. For instance, when CECs were treated with $1 \mu \mathrm{M}$ of LY2109761, they maintained their authentic polygonal cell shape during continuous subcultures. Furthermore, the characteristic subcellular locations of ZO- 1 and $\mathrm{Na}+/ \mathrm{K}+$-ATPase were perfectly resumed at the plasma membrane in the $1-\mu \mathrm{M}$ LY2109761-treated group. What's more, the expression of these two functional proteins was significantly increased at both the mRNA and protein levels. These results suggest that the barrier and pump function in LY2109761-treated CECs were better preserved than in the control group. Finally, the expression of mesenchymal markers, including fibronectin and vimentin, was significantly reduced in response to the 1- $\mu$ M LY2109761 treatment. These results indicate that the EnMT process was effectively inhibited during the cultivation of CECs treated with LY2109761. 


\section{Cellular Physiology Cell Physiol Biochem 2018;50:963-972 \begin{tabular}{ll|l} 
and Biochemistry & DOl: 10.1159/000494480 & $\begin{array}{l}\text { (c) } 2018 \text { The Author(s). Published by S. Karger AG, Basel } \\
\text { www.karger.com/cpb }\end{array}$
\end{tabular}}

Zhang et al.: LY2109761 Inhibits Endothelial Mesenchymal Transformation

\section{Conclusion}

In conclusion, LY2109761, a novel T $\beta R I$ and T $\beta R I I$ kinase selective inhibitor, can inhibit EnMT in vitro and enable the continuous expansion of CECs with a normal phenotype and function, which would be an ideal property for the engineering of functional corneal endothelium.

\section{Acknowledgements}

This work was supported by National Natural Science Foundations of China (81600704 and 81470638), Outstanding Academic Leaders Plan of Shanghai Municipal Commission of Health and Family Planning (2017BR056), Gaofeng Gaoyuan Clinical Medicine Grant Support of Shanghai Municipal Education Commission (20161426) and Interdisciplinary Program of Shanghai Jiao Tong University (YG2015QN19).

\section{Disclosure Statement}

The authors declare that there are no conflicts of interest.

\section{References}

1 Geroski DH, Matsuda M, Yee RW, Edelhauser HF: Pump function of the human corneal endothelium. Effects of age and cornea guttata. Ophthalmology 1985;92:759-763.

-2 Navaratnam J, Utheim TP, Rajasekhar VK, Shahdadfar A: Substrates for Expansion of Corneal Endothelial Cells towards Bioengineering of Human Corneal Endothelium. J Funct Biomater 2015;6:917-945.

-3 Okumura N, Kinoshita S, Koizumi N: Cell-based approach for treatment of corneal endothelial dysfunction. Cornea 2014;33 Suppl 11:S37-41.

-4 Zhang Z, Niu G, Choi JS, Giegengack M, Atala A, Soker S: Bioengineered multilayered human corneas from discarded human corneal tissue. Biomed Mater 2015;10:035012.

5 Beaulieu Leclerc V, Roy O, Santerre K, Proulx S: TGF- $\beta 1$ promotes cell barrier function upon maturation of corneal endothelial cells. Sci Rep 2018;8:4438.

6 Okumura N, Kay EP, Nakahara M, Hamuro J, Kinoshita S, Koizumi N: Inhibition of TGF- $\beta$ signaling enables human corneal endothelial cell expansion in vitro for use in regenerative medicine. PLoS One 2013;8:e58000.

7 Zhu YT, Chen HC, Chen SY, Tseng SC: Nuclear p120 catenin unlocks mitotic block of contact-inhibited human corneal endothelial monolayers without disrupting adherent junctions. J Cell Sci 2012;125:36363648.

-8 Sumioka T, Ikeda K, Okada Y, Yamanaka 0, Kitano A, Saika S: Inhibitory effect of blocking TGF-beta/Smad signal on injury-induced fibrosis of corneal endothelium. Mol Vis 2008;14:2272-2281.

-9 Miyamoto T, Sumioka T, Saika S: Endothelial mesenchymal transition: a therapeutic target in retrocorneal membrane. Cornea 2010;29 Suppl 1:S52-56.

$\rightarrow 10$ Buckner SL, Pruitt AN, Thomas CN, Amin MY, Miller LL, Wiley FE, Sabbatini ME: Di-N-octylphthalate acts as a proliferative agent in murine cell hepatocytes by regulating the levels of TGF- $\beta$ and pro-apoptotic proteins. Food Chem Toxicol 2017;111:166-175.

11 Bu JQ, Chen F: TGF- $\beta 1$ promotes cells invasion and migration by inducing epithelial mesenchymal transformation in oral squamous cell carcinoma. Eur Rev Med Pharmacol Sci 2017;21:2137-2144.

12 Stiemke MM, Edelhauser HF, Geroski DH: The developing corneal endothelium: correlation of morphology, hydration and Na/K ATPase pump site density. Curr Eye Res 1991;10:145-156.

13 Barry PA, Petroll WM, Andrews PM, Cavanagh HD, Jester JV: The spatial organization of corneal endothelial cytoskeletal proteins and their relationship to the apical junctional complex. Invest Ophthalmol Vis Sci 1995;36:1115-1124. 


\section{Cellular Physiology Cell Physiol Biochem 2018;50:963-972

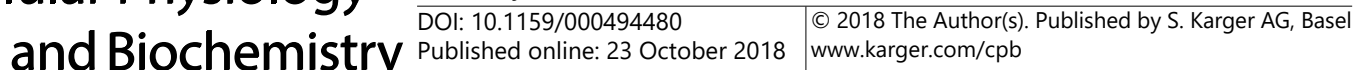

14 Okumura N, Hirano H, Numata R, Nakahara M, Ueno M, Hamuro J, Kinoshita S, Koizumi N: Cell surface markers of functional phenotypic corneal endothelial cells. Invest Ophthalmol Vis Sci 2014;55:7610-7618.

-15 Petroll WM, Jester JV, Bean JJ, Cavanagh HD: Myofibroblast transformation of cat corneal endothelium by transforming growth factor-beta1, -beta2, and -beta3. Invest Ophthalmol Vis Sci 1998;39:2018-2032.

-16 Usui T, Takase M, Kaji Y, Suzuki K, Ishida K, Tsuru T, Miyata K, Kawabata M, Yamashita H: Extracellular matrix production regulation by TGF-beta in corneal endothelial cells. Invest Ophthalmol Vis Sci 1998;39:1981-1989.

17 Polyak K, Weinberg RA: Transitions between epithelial and mesenchymal states: Acquisition of malignant and stem cell traits. Nat Rev Cancer 2009;9:265-273.

-18 Thiery JP, Acloque H, Huang RY, Nieto MA: Epithelial-mesenchymal transitions in development and disease. Cell 2009;139:871-890.

19 Price MO, Gupta P, Lass J, Price FW Jr: EK (DLEK, DSEK, DMEK): New Frontier in Cornea Surgery. Annu Rev Vis Sci 2017;3:69-90.

20 Flockerzi E, Maier P, Böhringer D, Reinshagen H, Kruse F, Cursiefen C, Reinhard T, Geerling G, Torun N, Seitz B; all German Keratoplasty Registry Contributors: Trends in Corneal Transplantation from 2001 to 2016 in Germany: A Report of the DOG-Section Cornea and its Keratoplasty Registry. Am J Ophthalmol 2018;188:91-98.

21 Bourne RRA, Flaxman SR, Braithwaite T, Cicinelli MV, Das A, Jonas JB, Keeffe J, Kempen JH, Leasher J, Limburg H, Naidoo K, Pesudovs K, Resnikoff S, Silvester A, Stevens GA, Tahhan N, Wong TY, Taylor HR; Vision Loss Expert Group: Magnitude, temporal trends, and projections of the global prevalence of blindness and distance and near vision impairment: a systematic review and meta-analysis. Lancet Glob Health 2017;5:e888-e897.

22 Gain P, Jullienne R, He Z, Aldossary M, Acquart S, Cognasse F, Thuret G: Global Survey of Corneal Transplantation and Eye Banking. JAMA Ophthalmol 2016;134:167-173.

23 Eye Bank Association of America 2016 Eye banking statistical report for 2016 (available from: www. restoresight.org).

24 Bartakova A, Kunzevitzky NJ, Goldberg JL: Regenerative Cell Therapy for Corneal Endothelium. Curr Ophthalmol Rep 2014;2:81-90.

-25 Jiang H, Sun HF, Gao SP, Li LD, Huang S, Hu X, Liu S, Wu J, Shao ZM, Jin W: SSBP1 Suppresses TGF- $\beta$-Driven Epithelial-to-Mesenchymal Transition and Metastasis in Triple-Negative Breast Cancer by Regulating Mitochondrial Retrograde Signaling. Cancer Res 2016;76:952-964.

-26 Chen Z, Ni N, Mei Y, Yang Z: LYTAK1 attenuates proliferation of retinal pigment epithelial cells through TGF- $\beta$-mediated epithelial-mesenchymal transition via the ERK/AKT signaling pathway. Exp Ther Med 2017;14:4951-4957.

-27 Engel ME, McDonnell MA, Law BK, Moses HL: Interdependent SMAD and JNK signaling in transforming growth factor-beta-mediated transcription. J Biol Chem 1999;274:37413-37420.

-28 Yu L, Hébert MC, Zhang YE: TGF-beta receptor-activated p38 MAP kinase mediates Smad-independent TGFbeta responses. EMBO J 2002;21:3749-3759.

29 Hocevar BA, Smine A, Xu XX, Howe PH: The adaptor molecule Disabled-2 links the transforming growth factor beta receptors to the Smad pathway. EMBO J 2001;20:2789-2801.

-30 Razani B, Zhang XL, Bitzer M, von Gersdorff G, Böttinger EP, Lisanti MP: Caveolin-1 regulates transforming growth factor (TGF)-beta/SMAD signaling through an interaction with the TGF-beta type I receptor. J Biol Chem 2001;276:6727-6738.

-31 Lawler S, Feng XH, Chen RH, Maruoka EM, Turck CW, Griswold-Prenner I, Derynck R: The type II transforming growth factor-beta receptor autophosphorylates not only on serine and threonine but also on tyrosine residues. J Biol Chem 1997;272:14850-14859.

-32 Bandyopadhyay B, Han A, Dai J, Fan J, Li Y, Chen M, Woodley DT, Li W: TbetaRI/Alk5-independent TbetaRII signaling to ERK1/2 in human skin cells according to distinct levels of TbetaRII expression. J Cell Sci 2011;124:19-24.

-33 Funaki T, Nakao A, Ebihara N, Setoguchi Y, Fukuchi Y, Okumura K, Ra C, Ogawa H, Kanai A: Smad7 suppresses the inhibitory effect of TGF-beta2 on corneal endothelial cell proliferation and accelerates corneal endothelial wound closure in vitro. Cornea 2003;22:153-159. 


\section{Cellular Physiology Cell Physiol Biochem 2018;50:963-972 \begin{tabular}{ll|l} 
DOl: 10.1159/000494480 & $\begin{array}{l}\text { O } 2018 \text { The Author(s). Published by S. Karger AG, Basel } \\
\text { www.karger.com/cpb }\end{array}$ \\
\hline
\end{tabular} \\ Zhang et al.: LY2109761 Inhibits Endothelial Mesenchymal Transformation}

-34 Chen Z, Ni N, Mei Y, Yang Z: LYTAK1 attenuates proliferation of retinal pigment epithelial cells through TGF- $\beta$-mediated epithelial-mesenchymal transition via the ERK/AKT signaling pathway. Exp Ther Med 2017;14:4951-4957.

-35 Schelker RC, Iberl S, Müller G, Hart C, Herr W, Grassinger J: TGF- $\beta 1$ and CXCL12 modulate proliferation and chemotherapy sensitivity of acute myeloid leukemia cells co-cultured with multipotent mesenchymal stromal cells. Hematology 2018;23:337-345.

-36 Si Y, Bai J, Wu J, Li Q, Mo Y, Fang R, Lai W: LncRNA PlncRNA-1 regulates proliferation and differentiation of hair follicle stem cells through TGF- $\beta 1$ mediated Wnt/ $\beta$-catenin signal pathway. Mol Med Rep 2018;17:1191-1197. 